\title{
ANCIENT HISTORY IN AFRICA AND AFRICA IN ANCIENT HISTORY
}

Luciano César Garcia Pinto ${ }^{1}$

A quick search for the term Africa (and its derivatives, such as the adjective Africani etc.) in the Library of Latin Texts - a great electronic text database that includes everything written in Latin (with the exception of parietal and epigraphic inscriptions) from Livius Andronicus ( $3^{\text {rd }}$ century BC) to the Second Vatican Council (ending in 1965) - presents as an impressive result 3,785 sentences where this word and related terms appear, distributed among over 290 authors. In the course of the twenty-two centuries covered by this database, the first three mentions are in the $5^{\text {th }}$ and $1^{\text {st }}$ centuries $A D$ and in the $1^{\text {st }}$ century $\mathrm{BC}$. If, in the case of the $1^{\text {st }}$ centuries before and after Christ, we are at the moment of the extensive territorial acquisitions of the Roman armies, the first position occupied by the $5^{\text {th }}$ century is explained by the intense intellectual and political activity of the greatest thinker born on African soil that the Latin speaking world has known: Augustine, Bishop of Hippo.

These few pieces of information - which do not consider, for instance, possible allusive mentions and, thus, not explicit and identifiable with a simple lexical search - only give a dimension of the constant presence of the African continent in the textual and cultural history of the Latin speaking world. How the paths of the history of this presence intersect with its study on African soil is the main proposal of this issue of Heródoto magazine.

The articles gathered in this issue of the magazine try to show the diversity of themes and research in the field of the relationship between the ancient world and the African continent, both for scholars living in Africa and for Brazilian researchers who dedicate themselves to the subject. The papers published here range from specific study themes of the ancient world and Africa to the topic of the presence of Ancient Africa in the classrooms in Brazil.

\footnotetext{
${ }^{1}$ Assistant Professor - Federal University of São Paulo, São Paulo, Brazil.

E-mail: lucianuscaesar@gmail.com
} 